\section{Peranan Karakteristik Dewan Direksi dan Struktur Kepemilikan dalam Pengungkapan Sukarela Perusahaan Publik Indonesia}

\author{
Jessica Yeo dan Meiliana Suparman \\ Program Sarjana Akuntansi, Universitas Internasional Batam \\ Batam, Indonesia
}

E-Mail : jessicayeochan@gmail.com
Submitted: AGUSTUS 2021

Accepted: NOVEMBER 2021

\begin{abstract}
The objective of this study is to demonstrate that characteristics of the board of directors and ownership structure influence the level of voluntary disclosure. Board of directors' characteristics include the board's size, composition, frequency of meetings, gender, expertise, and compensation. These attributes reflect the ownership structure, which includes foreign ownership, institutional ownership, and director ownership. Control variables include company size, firm age, leverage, profitability, and liquidity. This study utilized secondary data from 52 consumer goods companies listed on the Indonesia Stock Exchange for the period 2016 to 2020. In total, 228 observations were tested for hypotheses, after 32 outliers were removed from the data. The hypotheses were tested using panel regression with a Fixed Effect Model (FEM). The study found that all independent variables simultaneously have a significant impact on voluntary disclosures. According to the partial test (ttest), only the remuneration of directors and institutional ownership had a significant and positive effect on voluntary disclosures, while other variables had no significant impact. In addition, the foreign ownership variable had a significant affect on voluntary disclosure, however the direction is negative.
\end{abstract}

Keywords: voluntary disclosure, BoD characteristics, ownership structure

\begin{abstract}
ABSTRAK
Studi ini bertujuan membuktikan peranan dewan direksi dan struktur kepemilikan dalam tingkat pengungkapan sukarela. Karakteristik dewan direksi ditunjukkan melalui ukuran, komposisi, frekuensi rapat, gender, keahlian dan remunerasi direksi. Struktur kepemilikan diwakili oleh kepemilikan asing, institusional dan direksi. Ukuran, umur, leverage, profitabilitas dan likuiditas perusahaan digunakan sebagai variabel kontrol dalam pengujian hipotesis. Penelitian kuantitatif ini menggunakan data sekunder dari laporan tahunan 52 perusahaan industri barang konsumsi yang terdaftar di Bursa Efek Indonesia pada tahun 2016 hingga 2020. Data untuk uji hipotesis sebanyak 228 setelah dikeluarkan 32 outliers. Metode untuk menguji hipotesis adalah regresi panel dengan menggunakan Fixed Effect Model (FEM). Hasil studi menunjukkan bahwa seluruh variabel bebas secara simultan berpengaruh signifikan terhadap pengungkapan sukarela. Hasil uji secara parsial (uji t) memperlihatkan hanya remunerasi direksi dan kepemilikan institusional yang mempunyai pengaruh signifikan positif terhadap pengungkapan sukarela, sedangkan variabel lainnya tidak berpengaruh signifikan. Variabel kepemilikan asing menunjukkan pengaruh yang signifikan terhadap pengungkapan sukarela, namun arahnya negatif.
\end{abstract}

Kata Kunci: pengungkapan sukarela, karakteristik dewan direksi, struktur kepemilikan

\section{JIAKES}

Jurnal Ilmiah Akuntansi Kesatuan Vol. 9 No. 3,2021 pg. $511-522$
IBI Kesatuan ISSN $2337-7852$ E-ISSN $2721-3048$ DOI: $10.37641 /$ jiakes.v9i3.896 


\section{Voluntary PENDAHULUAN}

Disclosure of Public Pandemi Covid-19 memberikan dampak besar terhadap berbagai aspek kehidupan, Institution terutama pada aktivitas masyarakat dan perekonomian. Investasi dalam bentuk saham selama masa pandemi ini semakin bertumbuh (Firdaus, 2020). Saham merupakan bukti kepemilikan atas suatu perusahaan yang dapat diperjual-belikan di bursa efek/pasar saham. Perusahaan dengan status go public dapat menambah sumber dananya dengan cara menjual kepemilikan perusahaannya melalui pasar saham. Setiap perusahaan berusaha untuk memaksimalkan kinerjanya agar dapat meningkatkan sumber dana dan menarik lebih banyak investor (Audrey, 2021).

Berbagai bursa efek saat ini menuntut perusahaan menyediakan laporan keuangan untuk pemangku kepentingan dengan tepat waktu dan berkualitas tinggi. Informasi yang diungkapkan perusahaan ini berguna untuk membantu stakeholders membuat keputusan

\section{2} (Alhazaimeh et al., 2014). Pengungkapan yang dilakukan perusahaan dibagi menjadi dua, yakni pengungkapan wajib dan pengungkapan sukarela. Pengungkapan wajib merupakan pengungkapan yang diharuskan oleh pihak berwenang seperti Otoritas Jasa Keuangan (OJK) untuk dilaporkan oleh perusahaan (Neliana, 2018). Sedangkan untuk pengungkapan sukarela adalah pengungkapan yang dilakukan tanpa adanya paksaan oleh instansi lain, namun ditujukan untuk menambah nilai perusahaan di mata investor maupun stakeholders lainnya (Melyana \& Syafruddin, 2015).

Beberapa faktor yang dapat mempengaruhi tingkat pengungkapan suatu perusahaan seperti karakteristik perusahaan, dewan direksi, struktur kepemilikan, dan tingginya tuntutan akuntabilitas dan transparansi dari masyarakat. Perusahaan berskala besar, cenderung lebih luas dalam mengungkapkan informasi dibandingkan perusahaan kecil dan menengah (Sefty \& Farihah, 2016). Tingkat pengungkapan perusahaan juga dapat dipengaruhi oleh proporsi kepemilikan saham. Jika banyak pihak yang memerlukan informasi, maka semakin tinggi tingkat pengungkapan informasi (Nabor \& Suardana, 2014). Contoh lain, jika pemilik dan pengelola perusahaan memiliki kepentingan yang tidak selaras menyebabkan rendahnya pengungkapan perusahaan (Alim \& Ida, 2018).

Tata kelola perusahaan yang baik mampu memperkuat kontrol dan menjamin kualitas dari pengungkapan informasi laporan perusahaan sehingga kepercayaan di pasar modal tetap terjaga (Fitri, 2016). Tata kelola yang buruk menyebabkan berbagai kasus penipuan, sehingga tuntutan terhadap pengungkapan perusahaan. Perhatian terhadap praktik tata kelola perusahaan semakin meningkat (Kristie \& Robin, 2016).

Pengungkapan informasi yang semakin luas dapat mengurangi asimetri informasi antara manajemen dan investor perihal kondisi keuangan maupun hasil operasi perusahaan (Faisol, 2019). Penelitian tentang luasnya pengungkapan sukarela dan faktorfaktor yang mempengaruhinya menyajikan hasil yang bervariasi. Oleh sebab itu, penelitian mengenai pengungkapan sukarela pada laporan tahunan dan faktor yang mempengaruhinya masih perlu dilakukan. Pengujian terhadap perusahaan pada industri barang konsumsi dengan alasan bahwa sektor tersebut dengan jumlah perusahaan terbanyak di Bursa Efek Indonesia (BEI).

Pengungkapan sukarela adalah penyajian informasi perusahaan yang dilakukan secara leluasa sehingga mampu memberikan informasi tambahan yang diperlukan oleh penggunanya (Hidayat, 2017). Laporan tahunan harus disajikan dengan informasi yang mampu mendukung supaya informasi yang disajikan tidak menimbulkan kesalahan dalam penafsiran. Pengungkapan yang baik mampu memberikan sejumlah informasi yang dapat membantu para pembaca untuk memprediksi kinerja perusahaan di masa depan (Sembiring, 2012). Jika pengungkapan perusahaan semakin berkualitas dan luas, maka lebih efektif dan dapat digunakan secara maksimal oleh para pemangku kepentingan (Pratiwi, 2015). Ada tiga tingkatan dalam suatu pengungkapan perusahaan yaitu pengungkapan yang wajar, pengungkapan yang cukup dan pengungkapan secara penuh. Pengungkapan yang telah diatur ada dua jenis, yakni pengungkapan wajib dan pengungkapan sukarela (Neliana, 2018).

Pengungkapan wajib diatur oleh Ketua Bapepam Nomor: KEP-431/BL/2012 tentang penyampaian laporan tahunan emiten atau perusahaan publik dan harus ditaati oleh 
perusahaan go public. Peraturan mengenai pengungkapan wajib dalam laporan keuangan diatur dalam SK BAPEPAM No. Kep-347/BL/2012 (Wulandari \& Laksito, 2015). Saat ini pengungkapan wajib dianggap tidak cukup untuk menilai kinerja suatu perusahaan sehingga para pemangku kepentingan menuntut perusahaan untuk melakukan pengungkapan dalam bentuk lain (Sefty \& Farihah, 2016). Pengungkapan sukarela merupakan pengungkapan yang dilakukan secara leluasa oleh manajemen perusahaan sesuai kebijakan perusahaan untuk memberikan informasi yang lebih banyak kepada investor (Saputra, 2014). Adanya pengungkapan sukarela menjadi saran bagi investor untuk menilai perusahaan tersebut merupakan perusahaan yang baik atau buruk (Nofianti et al., 2018). Informasi dalam laporan dapat disajikan dalam bentuk: laporan keuangan, catatan atas laporan keuangan, penggunaan istilah teknis, lampiran, pernyataan resmi dan penjelasan lainnya (Sambudi \& Maharani, 2019).

Dewan direksi merupakan elemen dasar dalam sistem tata kelola perusahaan. Ukuran atau jumlahanggota dewan dipercaya dapat mempengaruhi cara dimana direktur menjalankan tanggung jawabnya (Alfraih \& Almutawa, 2017). Ukuran dewan direksi berperan penting dalam mempromosikan transparansi perusahaan (Samaha et al., 2014). Menurut Al-janadi \& Alazzani (2016), Alfraih \& Almutawa (2017) dan Maskati \& Hamdan (2017), ukuran dewan direksi memberikan pengaruh signifikan positif terhadap pengungkapan sukarela. Jumlah dewan yang lebih besar membawa keragaman keahlian, sehingga memberikan kemampuan lebih kepada dewan untuk melaksanakan kegiatannya dan memberikan informasi kepada pemegang saham (Zaheer, 2013). Penipuan juga dapat menurun seiring dengan peningkatan ukuran dewan dan sebaliknya. Jika ukuran dewan direksi kecil, maka memiliki kemampuan pemrosesan informasi yang terbatas (Alfraih \& Almutawa, 2017). Namun penelitian Alfraih \& Almutawa, 2017 mengungkapkan bahwa ukuran dewan direksi berpengaruh signifikan negatif dengan tingkat pengungkapan sukarela. Meningkatnya jumlah anggota direksi menurunkan perhatian terhadap pentingnya penerapan pelaporan sukarela dan kualitasnya. Penelitian yang dilakukan oleh Alhazaimeh et al. (2014) dan Serly (2015) menunjukkan bahwa ukuran dewan direksi tidak berpengaruh signifikan terhadap pengungkapan sukarela. Jumlah dewan yang tinggi mengurangi kemampuan penyampaian informasi dalam pengungkapan laporan tahunan perusahaan (Ramadhan, 2014).

Dewan direksi umumnya mempunyai direksi dari unsur independen. Direksi independen adalah anggota yang tidak memiliki hubungan apapun dengan siapapun dalam perusahaan (Rouf, 2016). Komposisi direksi independen berpengaruh signifikan positif terhadap pengungkapan sukarela Samaha et al. (2014), Elfeky (2017), Maskati \& Hamdan (2017) dan García-meca \& Sánchez-ballesta (2010). Hal ini disebabkan karena hasil pemantauan lebih efektif selama anggota dewan tidak bias. Demikian juga temuan dari Bueno et al. (2018) dan Zaheer (2013) yang menyatakan bahwa jumlah anggota dewan direksi independen tidak mempengaruhi pengungkapan informasi sukarela. Banyak manfaat yang didapatkan perusahaan jika memiliki direksi independen tetapi dalam segi pengawasan.

Dewan direksi dalam melaksanakan tanggungjawabnya perlu melakukan rapat untuk membahas berbagai hal terkait strategi dan pelaksanaan pengawasan manajemen (Rodríguez Domínguez \& Noguera Gámez, 2014). Alnabsha et al. (2018) menyatakan bahwa frekuensi rapat dewan direksi berpengaruh signifikan positif pada pengungkapan sukarela. Apabila rapat direksi sering dilakukan, maka dapat meningkatkan informasi yang disajikan oleh direksi. Penelitian Albawwat \& Ali basah (2015), Alhazaimeh et al. (2014) dan Serly (2015) menunjukkan hal sebaliknya, dimana frekuensi rapat direksi tidak memiliki pengaruh signifikan terhadap pengungkapan sukarela. Hasil ini disebabkan oleh kebijakan rapat direksi setiap perusahaan yang berbeda. Selain itu, dewan direksi membutuhkan pengetahuan yang mendalam dan pembaruan tentang aktivitas perusahaan (Barros, 2013).

Dewan direksi suatu perusahaan keragaman gendernya dikatakan dapat memberikan perspektif, norma dan nilai berbeda dalam pengambilan keputusan. Keberagaman gender dapat meningkatkan pengetahuan dan ide sehingga menjadi suatu kelebihan bagi
Disclosure of Public

Institution

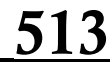


Voluntary

Disclosure of Public

Institution

514

perusahaan. Hasil penelitian yang dilakukan Kartikarini \& Mutmainah (2013), Vedanti Pratiwi et al. (2018) dan Rouf (2016) menyimpulkan bahwa komposisi direksi wanita memiliki pengaruh signifikan positif terhadap pengungkapan sukarela. Selain itu, direksi wanita cenderung lebih suka melakukan pertemuan, sehingga bisa meningkatkan pengungkapan informasi (Sartawi et al., 2014). Penelitian Fitri (2016) mengungkapkan sebaliknya, bahwa komposisi direksi wanita tidak berpengaruh signifikan terhadap pengungkapan sukarela. Wanita memiliki kecenderungan takut dalam mengambil suatu keputusan dan risiko dibandingkan pria. Hal ini membuat keberadaan direksi wanita tidak terlalu terlihat berpengaruh pada tingkat informasi yang disajikan.

Dewan direksi terdidik dapat melihat sesuatu dengan cara yang lebih baik dan lebih luas. Latar belakang pendidikan direksi disebut dapat menjadi penentu penting pengungkapan informasi (Akhtaruddin \& Abdur Rouf, 2012). Menurut Akhtaruddin \& Abdur Rouf (2012), komposisi direksi dengan gelar ekonomi mempunyai peranan signifikan dan positif terhadap pengungkapan sukarela. Pola pikir direksi dengan latar belakang pendidikan ekonomi memiliki pemahaman lebih terkait kebutuhan analisa sehingga mengekspos lebih banyak informasi. Berdasarkan hasil Fitri, 2016, komposisi direksi bergelar ekonomi tidak berpengaruh signifikan terhadap pengungkapan sukarela. Direksi dengan ilmu tertentu yang sesuai dengan kebutuhan bisnis perusahaan dapat menunjang keberlangsungan usaha. Selain itu, direksi yang memiliki latar belakang pendidikan yang bervariasi dapat menghasilkan keputusan yang lebih berani dan inovatif. Pendidikan yang diperoleh dari institusi pendidikan hanya sebuah hard skill sedangkan saat ini soft skill dirasa lebih penting.

Dewan direksi berkebangsaan asing dipercayai dapat membantu meyakinkan investor asing. Perusahaan mempunyai citra dikelola secara profesional untuk kepentingan terbaik investor asing. Berdasarkan penelitian Vedanti Pratiwi et al. (2018) dan Rasmini et al. (2014), diversitas kewarganegaraan direksi berpengaruh signifikan positif pada pengungkapan informasi. Direksi asing mampu menambah nilai perusahaan karena memiliki pengalaman yang tidak dimiliki oleh direksi lokal. Sedangkan penelitian yang dilakukan oleh Agyemang et al. (2020) menunjukkan bahwa direksi asing tidak berpengaruh secara signifikan terhadap luasnya pengungkapan laporan karena keterbatasan bahasa dan geografis.

Salah satu karakterisitik dewan direksi yang sering diteliti adalah kompensasi direksi. Penelitian Albawwat \& Ali basah (2015) dan Alhazaimeh et al. (2014) menyatakan bahwa remunerasi direksi berpengaruh signifikan positif terhadap luasnya pengungkapan sukarela. Pemberian kompensasi pada dewan direktur dapat meningkatkan pengamatan pada manfaat seperti bonus dan kompensasi sehingga perilaku oportunisme manajerial meningkat. Remunerasi direksi yang lebih tinggi mendesak direksi untuk mengungkapkan informasi yang lebih tinggi karena mereka memiliki rasa tanggungjawab yang lebih besar. Dalam penelitian Roudaki (2018) mengungkapkan bahwa kompensasi direksi tidak memiliki pengaruh signifikan terhadap kinerja perusahaan karena kompensasi yang tinggi pada direksi dapat menyebabkan direksi kurang termotivasi untuk meningkatkan kinerjanya yang membuat pengungkapan cenderung tetap dan sama.

Struktur kepemilikan dianggap sebagai faktor yang mempengaruhi kualitas laporan keuangan (Alhazaimeh et al., 2014). Tingkat luasnya pengungkapan perusahaan dipengaruhi oleh perbedaan proporsi saham milik investor (Nabor \& Suardana, 2014). Penelitian Samaha et al. (2014) dan Fitri (2016) menyatakan bahwa terdapat hubungan signifikan positif antara kepemilikan asing dengan tingkat pengungkapan sukarela. Hasil ini memberikan dukungan untuk teori keagenan, yang menunjukkan bahwa perusahaan dengan tingkat kepemilikan asing yang tinggi diharapkan menyajikan lebih banyak informasi. Investor asing juga menuntut tingkat keterlibatan yang lebih besar dalam pengungkapan sukarela untuk membenarkan investasi mereka di perusahaan luar negeri. Penelitian Taran et al. (2017) mengungkapkan bahwa kepemilikan asing memiliki pengaruh signifikan namun arahnya negatif terhadap luasnya pengungkapan sukarela. Hasil penelitian Wijayani et al. (2019), El-diftar et al. (2017) dan Albawwat \& Ali basah 
(2015) menunjukkan bahwa kepemilikan asing tidak memiliki pengaruh signifikan terhadap luasnya pengungkapan sukarela. Perusahaan yang dipegang oleh pemegang saham asing cenderung akan menghadapi permasalahan asimetri informasi akibat bahasa dan geografis (Hidayat, 2017).

Kepemilikan institusional merupakan jumlah saham yang dipegang oleh lembaga seperti asuransi, bank dan institusi lainnya (Nainggolan, 2017). Penelitian Wijayani et al. (2019), Nainggolan (2017), Mahayana \& Bagiada (2015), Ntim et al. (2012) dan Uyar et al. (2013) memperlihatkan bahwa kepemilikan institusional mempunyai pengaruh signifikan positif terhadap pengungkapan sukarela. Pemegang saham mayoritas umumnya memiliki inisiatif untuk mengontrol dan memantau operasi perusahaan. Hal ini menyebabkan peningkatan kinerja atau nilai perusahaan karena perusahaan telah dikelola dengan baik (Soejono, 2010). Hal ini terjadi karena tingginya kepemilikan institusional dapat mendorong perusahaan untuk melakukan pengungkapan yang lebih luas. Tata kelola perusahaan dipercayai dapat ditingkatkan dengan memberikan peran yang lebih besar kepada investor dalam memantau praktik manajemen. Biasanya pemilik saham institusional lebih memiliki insiatif untuk memantau perusahaan yang mereka miliki, tidak seperti investor individu. Hasil penelitian dari Yunita (2012) dan Nabor \& Suardana (2014) menunjukkan bahwa kepemilikan institusional tidak memiliki pengaruh signifikan yang terhadap pengungkapan sukarela. Pemegang saham menganggap bahwa pengungkapan sukarela hanya pengungkapan tambahan yang bersifat tidak wajib.

Kepemilikan saham perusahaan oleh direksi dapat mendorong direksi untuk bertindak layaknya sebagai pemilik. Perusahaan akan dikelola oleh manajemen dengan lebih baik. Penelitian Mohd Ghazali \& Weetman (2006) dan Alnabsha et al. (2018) menunjukkan bahwa kepemilikan direksi berpengaruh signifikan terhadap luasnya pengungkapan informasi. Kepemilikan manajerial yang tinggi dapat berfungsi sebagai cara untuk menyelaraskan kepentingan manajer dengan kepentingan pemegang saham, sehingga dapat meningkatkan pengungkapan. (Nainggolan, 2017). Penelitian (Leung \& Horwitz, 2004) menunjukkan bahwa kepemilikan dewan direksi tidak berpengaruh signifikan terhadap luasnya pengungkapan informasi dan penelitian Akhtaruddin \& Haron (2010) mengungkapkan kepemilikan dewan berpengaruh signifikan negatif terhadap pengungkapan informasi laporan. Sebuah perusahaan kepemilikan dewan yang tinggi akan mencegah pengungkapan informasi ke pesaing sehingga meningkatkan asimetri informasi.

\section{Model Penelitian}
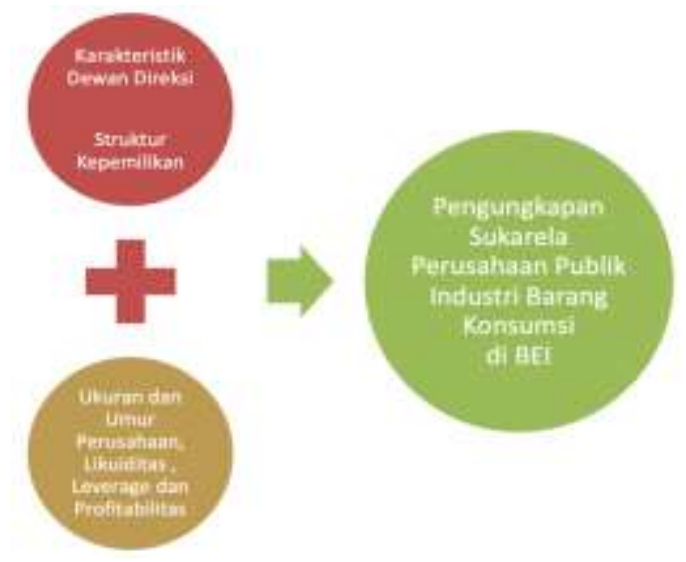

\section{Hipotesis}

Studi ini menggunakan ukuran perusahaan, umur perusahaan, leverage, profitabilitas dan likuiditas sebagai variabel kontrol dalam pengujian hipotesis. Berikut hipotesis yang dirumuskan berdasarkan uraian tinjauan pustaka dari hasil penelitian sebelumnya dan model penelitian yang dikembangkan:

$\mathrm{H}_{1}$ : Karakteristik Dewan Direksi (ukuran, komposisi, frekuensi rapat, gender, keahlian dan remunerasi) mempunyai pengaruh signifikan positif terhadap
Voluntary

Disclosure of Public

Institution

515 
Voluntary

Disclosure of Public Institution

$\underline{516}$

pengungkapan sukarela perusahaan publik di Indonesia.

$\mathrm{H}_{2}$ : Struktur Kepemilikan (asing, institusional dan direksi) mempunyai pengaruh signifikan positif terhadap pengungkapan sukarela perusahaan publik di Indonesia.

\section{METODE PENELITIAN}

Penelitian kuantitatif ini termasuk penelitian kausal komparatif. Objek penelitian adalah perusahaan industri barang konsumsi yang terdaftar di Bursa Efek Indonesia pada tahun 2016 hingga 2020. Perusahaan diseleksi dengan metode purposive sampling dan diperoleh 52 perusahaan yang terpilih sebagai sampel. Penelitian ini menggunakan data sekunder dari laporan tahunan perusahaan sampel yang telah diaudit. Laporan tahunan diunduh dari www.idx.co.id dan situs resmi perusahaan. Total data yang dikumpulkan berjumlah 260. Terdapat 32 data outliers yang dikeluarkan, sehingga data yang digunakan dalam pengujian hipotesis sebanyak 228. Data pada setiap variabel penelitian diukur mengikuti ketentuan yang diringkas dalam Tabel 1 berikut ini:

Tabel 1. Definisi Operasional Variabel

\begin{tabular}{l} 
Variabel \\
\hline Dependen: \\
- Pengungkapan Sukarela \\
(PS)
\end{tabular}

Definisi Operasional Variabel

Pengungkapan sukarela merupakan rasio jumlah dari skor seluruh item yang diungkapkan perusahaan dibagi total item. Instrumen pengukuran yang digunakan diadopsi dari penelitian Alnabsha et al (2018). Cara pengukuran dengan memberikan skor 1 untuk item yang diungkapkan perusahaan dan 0 buat yang tidak diungkapkan. Terdapat 108 poin untuk pengukuran ini yang terdiri dari informasi umum, tata kelola perusahaan, ketentuan akuntansi, laporan laba rugi, neraca, arus kas, catatan atas laporan keuangan, informasi CSR dan prospek masa depan (Alnabsha et al., 2018).

\begin{tabular}{|c|c|}
\hline $\begin{array}{l}\text { Independen: } \\
\text { - Ukuran Direksi (UDD) }\end{array}$ & $\begin{array}{l}\text { Jumlah keseluruhan dewan direksi dalam sebuah perusahaan (Alnabsha } \\
\text { et al., 2018) }\end{array}$ \\
\hline $\begin{array}{l}\text { - Komposisi Direksi } \\
\text { Independen (KDI) }\end{array}$ & $\begin{array}{l}\text { Jumlah dari direksi independen dibagi dengan total direksi (Alnabsha et } \\
\text { al., 2018). }\end{array}$ \\
\hline $\begin{array}{l}\text { - Frekuensi Rapat Direksi } \\
\text { (FRD) }\end{array}$ & $\begin{array}{l}\text { Jumlah rapat yang diadakan oleh dewan direksi dalam satu tahun } \\
\text { (Alnabsha et al., 2018). }\end{array}$ \\
\hline $\begin{array}{l}\text { - Komposisi direksi wanita } \\
\text { (KDW) }\end{array}$ & $\begin{array}{l}\text { Jumlah direksi berjenis kelamin wanita dibagi dengan total direksi } \\
\text { (Fitri, 2016) }\end{array}$ \\
\hline $\begin{array}{l}\text { - Komposisi Direksi Bergelar } \\
\text { Ekonomi (KDE) }\end{array}$ & $\begin{array}{l}\text { Jumlah direksi dengan gelar di bidang ekonomi dibagi total direksi } \\
\text { (Fitri, 2016). }\end{array}$ \\
\hline $\begin{array}{l}\text { - Komposisi direksi asing } \\
\text { (KDA) }\end{array}$ & Rasio dari jumlah direksi asing dibagi total direksi (Astuti, 2017). \\
\hline $\begin{array}{l}\text { - Remunerasi direksi } \\
\text { (LnRD)* }\end{array}$ & $\begin{array}{l}\text { Logartima natural dari gaji dan tunjangan yang berkaitan dengan } \\
\text { kinerja direksi. }\end{array}$ \\
\hline - Kepemilikan asing (KA) & $\begin{array}{l}\text { Perbandingan jumlah saham milik investor asing dengan jumlah saham } \\
\text { beredar (Alnabsha et al., 2018) }\end{array}$ \\
\hline $\begin{array}{l}\text { - Kepemilikan institusional } \\
\text { (KI) }\end{array}$ & $\begin{array}{l}\text { kepemilikan saham institusi dibandingkan dengan total saham beredar. } \\
\text { (Alnabsha et al., 2018) }\end{array}$ \\
\hline - Kepemilikan direksi (KD) & $\begin{array}{l}\text { kepemilikan saham direksi pada perusahaan dibandingkan dengan total } \\
\text { saham beredar (Alnabsha et al., 2018). }\end{array}$ \\
\hline $\begin{array}{l}\text { Kontrol: } \\
\text { - Ukuran perusahaan } \\
(\text { LnUP)* }\end{array}$ & $\begin{array}{l}\text { Kemampuan perusahaan dalam mengelola aset = logaritma natural dari } \\
\text { jumlah aktiva perusahaan (Alnabsha et al., 2018). }\end{array}$ \\
\hline - Umur perusahaan (FA) & $\begin{array}{l}\text { Jumlah tahun sejak perusahaan didirikan sampai periode penelitian } \\
\text { (Alnabsha et al., 2018). }\end{array}$ \\
\hline - Leverage (LEV) & $\begin{array}{l}\text { Indikator yang mengukur bagian dari setiap rupiah modal sendiri yang } \\
\text { dijadikan sebagai jaminan hutang jangka panjang = Kewajiban/Ekuitas } \\
\text { (Alnabsha et al., 2018). }\end{array}$ \\
\hline - Profitabilitas (PRO) & $\begin{array}{l}\text { Kemampuan suatu perusahaan untuk menghasilkan laba = Laba Tahun } \\
\text { Berjalan/Ekuitas (Alnabsha et al., 2018). }\end{array}$ \\
\hline - Likuiditas (LIK) & $\begin{array}{l}\text { Kemampuan perusahaan memenuhi kewajiban jangka pendeknya }= \\
\text { Aset Lancar/Kewajiban Lancar (Alnabsha et al., 2018). }\end{array}$ \\
\hline
\end{tabular}


Analisis terhadap data diawali dengan uji statistik deskriptif dan outlier. Hipotesis diuji dengan metode regresi panel karena data penelitian mempunyai sifat perpaduan antara data cross section dan time series. Pemilihan model regresi terbaik dilakukan melalui $U j i$ Chow dengan melihat angka signifikansi Chi-Square dan Uji Hausman yang ditunjukkan oleh signifikansi Cross Section Random. Jika signifikansi Chi-Square Uji Chow lebih tinggi dari 0,05 , maka model terbaik untuk digunakan dalam uji hipotesis adalah pool least square (PLS). Sebaliknya jika signifikansi Uji Chow kurang dari 0,05 , maka harus dilakukan tahap berikutnya dengan melakukan Uji Hausman. Jika probabilitas Uji Hausman lebih dari 0,05 , maka model terbaik yang dipilih adalah random effect model (REM). Sebaliknya jika probabilitas kurang dari 0,05, maka fixed effect model (FEM) yang digunakan dalam uji hipotesis. Pembuktian hipotesis menggunakan angka signifikansi hasil uji t. Jika signifikansi lebih kecil dari 0,05, maka hipotesis terbukti dan sebaliknya. Selain itu dibahas juga hasil pengujian secara simultan dari uji $\mathrm{F}$ dan uji koefisien determinasi (Singgih santoso, 2014).

\section{HASIL DAN PEMBAHASAN}

\section{Statistik Deskriptif}

Hasil uji statistik deskriptif pada Tabel 2 di bawah ini menunjukkan bahwa sebagian besar perusahaan publik Indonesia pada industri barang konsumsi mempunyai tingkat pengungkapan sukarela yang tinggi, yaitu $77 \%$. Perusahaan sampel ada yang tidak mempunyai direktur independen, direksi dengan latar belakang keahlian bidang ekonomi/bisnis, direksi berjenis kelamin wanita dan juga keberadaan direksi asing serta kepemilikan saham oleh direksi. Perusahaan sampel juga ada yang mempunyai Leverage dan Profitabilias yang negatif.

Tabel 2. Statistik deskriptif setelah uji outlier

\begin{tabular}{lccccc}
\hline Keterangan & N & Minimum & Maksimum & Rata-Rata Std. Deviasi \\
\hline Pengungkapan Sukarela (PS) & 228 & 0,7100 & 0,8300 & 0,7700 & 0,0220 \\
Ukuran Direksi (UDD) & 228 & 2,0000 & 11,0000 & 5,0700 & 2,0300 \\
Komposisi Direksi Independen (KDI) & 228 & 0,0000 & 0,5000 & 0,1642 & 0,1395 \\
Frekuensi Rapat Direksi (FRD) & 228 & 4,0000 & 38,0000 & 14,0000 & 6,0000 \\
Komposisi Direksi Bergelar Ekonomi (KDE) & 228 & 0,0000 & 1,0000 & 0,6688 & 0,2375 \\
Komposisi Direksi Wanita (KDW) & 228 & 0,0000 & 0,6700 & 0,1819 & 0,1977 \\
Komposisi Direksi Asing (KDA) & 228 & 0,0000 & 0,8000 & 0,1608 & 0,2423 \\
Remunerasi Direksi (LnRD) & 228 & 20,0600 & 25,5000 & 23,2331 & 1,1805 \\
Kepemilikan Asing (KA) & 228 & 0,0000 & 1,0000 & 0,3170 & 0,3244 \\
Kepemilikan Institusional (KI) & 228 & 0,1700 & 1,0000 & 0,8327 & 0,1777 \\
Kepemilikan Direksi (KD) & 228 & 0,0000 & 0,0600 & 0,0042 & 0,0116 \\
Ukuran Perusahaan (LnUP) & 228 & 24,6100 & 31,5600 & 28,7118 & 1,3963 \\
Umur Perusahaan (FA) & 228 & 5,0000 & 88,0000 & 38,6300 & 17,1140 \\
Leverage (LEV) & 228 & $-3,140$ & 6,2000 & 1,0939 & 0,9877 \\
Profitabilitas (PRO) & 228 & $-1,3500$ & 1,4300 & 0,0600 & 0,3130 \\
Likuiditas (LIK) & 228 & 0,0600 & 10,2500 & 2,1553 & 1,8081 \\
\hline Sumber: Data diolah dencen
\end{tabular}

Sumber: Data diolah dengan e-views (2021)

\section{Pemilihan Model}

Hasil Uji Chow menunjukkan bahwa signifikansi Chi-Square adalah 0,0000 $(<0,05)$. Hasil ini mengarahkan bahwa penentuan model penelitian yang terbaik untuk digunakan harus melalui Uji Hausman. Hasil dari Uji Hausman diperoleh nilai probabilitas sebesar $0,0019(<0,05)$. Disimpulkan bahwa model terbaik dari penelitian ini adalah Fixed Effect Model (FEM).

\section{Hasil Uji F dan Koefisien Determinasi}

Hasil uji F (uji secara simultan) menunjukkan angka probabilitas sebesar 0,0000. Hal ini artinya seluruh variabel independen secara simultan memiliki pengaruh signifikan terhadap pengungkapan sukarela. Hasil uji koefisien determinasi menunjukkan angka Adjusted R-Square sebesar 99,19\%. Arti dari angka Adjusted $\mathrm{R}^{2}$ tersebut adalah variabel independen mampu menjelaskan perubahan pada pengungkapan sukarela sebesar $99,19 \%$ sedangkan $0,81 \%$ dipengaruh oleh variabel lain. Contoh variabel lain yang dapat mempengaruhinya seperti industri atau jenis usaha, struktur kepemilikan, tingkat
Disclosure of Public

Institution

517 
Voluntary

Disclosure of Public

Institution

\section{8}

likuiditas, tingkat profitabilitas, ukuran perusahaan (Subair, 2013).

\section{Hasil Uji Hipotesis}

Pengaruh tiap variabel dapat dilihat dari hasil uji t (uji secara parsial) yang dirangkum dalam Tabel 3. Variabel kontrol dalam penelitian ini terlihat seluruhnya tidak mempunyai pengaruh yang dignifikan terhadap pengungkapan sukarela. Variabel independen menunjukkan hasil sebagai berikut:

Tabel 3. Hasil uji t

\begin{tabular}{lcccc}
\hline Variabel & Koefisien & Prob & Hasil Uji t & Hipotesis \\
\hline Constant & 0,7757 & 0,0000 & - & - \\
Ukuran Direksi (UDD) & $-0,0003$ & 0,1618 & Tidak signifikan & Tidak Terbukti \\
Komposisi Direksi Independen (KDI & 0,0002 & 0,8796 & Tidak signifikan & Tidak Terbukti \\
Frekuensi Rapat Direksi (FRD) & $-5,2700$ & 0,4582 & Tidak signifikan & Tidak Terbukti \\
Komposisi Direksi Wanita (KDW) & $-0,0004$ & 0,8166 & Tidak signifikan & Tidak Terbukti \\
Komposisi Direksi Bgelar Ekonomi & $-0,0010$ & 0,5211 & Tidak signifikan & Tidak Terbukti \\
Komposisi Direksi Asing (KDA) & $-0,0004$ & 0,8702 & Tidak signifikan & Tidak Terbukti \\
Remunerasi Direksi (LnRD) & 0,0017 & 0,0007 & Signifikan + & Terbukti \\
Kepemilikan Asing (KA) & $-0,0121$ & 0,0000 & Signifikan - & Tidak Terbukti \\
Kepemilikan Institusional (KI) & 0,0076 & 0,0069 & Signifikan + & Terbukti \\
Kepemilikan Direksi (KD) & $-0,0073$ & 0,8426 & Tidak signifikan & Tidak Terbukti \\
Ukuran Perusahaan (LnUP) & $-0,0014$ & 0,1146 & Tidak signifikan & - \\
Umur Perusahaan (FA) & $-4,5900$ & 0,6813 & Tidak signifikan & - \\
Leverage (LEV) & 9,4000 & 0,7655 & Tidak signifikan & - \\
Profitabilitas (PRO) & $-0,0013$ & 0,1305 & Tidak signifikan & - \\
Likuiditas (LIK) & $-0,0001$ & 0,2953 & Tidak signifikan & - \\
\hline Probabilitas F-test = 0,0000 & $\mathrm{R}^{2}=99,41$ & \multicolumn{2}{c}{ Adjusted R ${ }^{2}=99,19$}
\end{tabular}

Persamaan regresi:

$\mathrm{PS}=-0,0003 \mathrm{UDD}+$ 0,0002 KDI - 5,2700 FRD - 0,0004 KDW - 0,0010 KDE - 0,0004 KDA + 0,0017 LnRD - 0,0121 KA + 0,0076 KI - 0,0076 KD - 0,0014 LnUP - 4,5900 FA + 9,4000 LEV - 0,0013 PRO - 0,0001 LIK

Sumber: Data diolah dengan e-views (2021)

Hasil pengujian pada Tabel 3 hanya remunerasi direksi yang menunjukkan pengaruh signifikan dengan koefisien positif terhadap pengungkapan sukarela. Nilai probabilitas pada variabel remunerasi direksi sebesar 0,0007 dengan koefisien 0,0017. Hasil ini dapat membuktikan hipotesis yang diajukan bahwa remunerasi direksi berpengaruh signifikan positif terhadap pengungkapan sukarela. Hasil uji ini sejalan dengan Albawwat \& Ali basah, 2015 dan Alhazaimeh et al., 2014. Remunerasi direksi yang lebih tinggi membuat direksi merasa memiliki tanggungjawab yang lebih besar sehingga mendesak direksi untuk mengungkapkan informasi yang lebih tinggi. Variabel lainnya dari karakteristik dewan direksi tidak memiliki pengaruh signifikan terhadap pengungkapan sukarela (Hipotesis tidak terbukti). Ukuran dewan direksi menunjukkan nilai probabilitas sebesar 0,1618. Hasil ini selaras dengan hasil penelitian Alhazaimeh et al. (2014) dan Serly (2015). Hasil pengujian ini membuktikan bahwa jumlah direksi yang banyak membuat komunikasi dan pengambilan keputusan menjadi kurang efektif. Jumlah dewan yang tinggi mengurangi kemampuan penyampaian informasi dalam pengungkapan laporan tahunan perusahaan (Ramadhan, 2014).

Probabilitas komposisi direksi independen sebesar 0,8796 (Hipotesis tidak terbukti). Hasil pengujian ini konsisten dengan penelitian yang dilakukan oleh Bueno et al. (2018) dan Zaheer (2013). Banyak manfaat memiliki direksi independen seperti pemantauan yang lebih baik, sedikit kemungkinan terjadinya penipuan dan perlindungan hak-hak pemegang saham. Namun kehadiran direksi independen tidak terlalu mempengaruhi tingkat pengungkapan sukarela (Zaheer, 2013). Demikian juga hasil pengujian atas frekuensi rapat direksi, hipotesis ditolak (sig. 0,4582). Variabel ini tidak berpengaruh signifikan terhadap pengungkapan sukarela. Hasil ini sejalan dengan penelitian Albawwat \& Ali basah (2015), Alhazaimeh et al. (2014) dan Serly (2015). Mereka menjelaskan bahwa setiap perusahaan memiliki kebijakan rapatnya tersendiri sehingga tidak mempengaruhi keluasan pengungkapan sukarela. 
Keberadaan direksi wanita juga terbukti tidak berpengaruh terhadap pengungkapan sukarela karena probabilitas sebesar 0,8166 (Hipotesis tidak terbukti). Hasil penelitian ini dijelaskan oleh Fitri (2016) bahwa wanita memiliki kecenderungan kurang yakin dalam mengambil suatu keputusan sehingga membuat keberadaan tidak terlalu terlihat yang berpengaruh pada tingkat informasi yang dilaporkan.

Komposisi direksi dengan gelar ekonomi menunjukkan nilai probabilitas sebesar 0,5211. Hal ini berarti menyatakan bahwa komposisi direksi dengan latar belakang pendidikan di bidang ekonomi tidak berpengaruh signifikan pada pengungkapan sukarela (Hipotesis tidak terbukti). Penjelasan dari hasil penelitian Fitri (2016) menyatakan bahwa direksi dengan ilmu yang sesuai dengan kebutuhan perusahaan (tidak hanya ekonomi) akan meningkatkan keberlangsungan perusahaan tersebut. Selain itu, saat ini soft skill dirasa lebih penting.

Hipotesis tentang keberadaan direksi asing berpengaruh signifikan positif terhadap pengungkapan sukarela juga tidak terbukti. Hasil pengujian menunjukkan nilai probabilitas sebesar 0,8702. Hasil dari pengujian ini bertolakbelakang dengan hasil penelitian Vedanti Pratiwi et al. (2018) dan Rasmini et al. (2014). Hal ini menunjukkan bahwa kualitas direksi dari dalam negeri tidak memiliki perbedaan yang signifikan dengan kualitas direksi dari luar negeri.

Variabel kepemilikan asing pada Tabel 3 memiliki angka koefisien -0,0121 dengan probabilitas 0,0000 . hasil ini tidak mendukung hipotesis yang diajukan karena berarti kepemilikan asing memiliki pengaruh signifikan namun arahnya negatif terhadap pengungkapan sukarela. Semakin tinggi kepemilikan asing, maka pengungkapan sukarela makin menurun. Hasil uji sesuai dengan penelitian yang dilakukan Taran et al. (2017). Investor asing memiliki keterbatasan bahasa dan geografis, sehingga tidak dapat menuntut pengungkapan informasi yang tinggi (Hidayat, 2017).

Kepemilikan institusional memiliki nilai probabilitas 0,0069 dengan koefisien sebesar 0,0076. Berdasarkan hasil ini dapat disimpulkan bahwa kepemilikan institusional berpengaruh signifikan positif terhadap pengungkapan sukarela (Hipotesis terbukti). Hasil pengujian ini konsisten dengan penelitian Wijayani et al. (2019), Nainggolan, (2017), Mahayana \& Bagiada (2015), Ntim et al. (2012) dan Uyar et al. (2013). Penjelasan atas hasil ini adalah pemilik saham institusional biasanya lebih memiliki insiatif untuk memantau perusahaan yang mereka miliki, tidak seperti investor individu.

Pengujian regresi panel menunjukkan bahwa kepemilikan dewan direksi nilai probabilitasnya sebesar 0,8426 . Angka ini menunjukkan bahwa tidak ada pengaruh signifikan kepemilikan dewan direksi terhadap pengungkapan sukarela (Hipotesis tidak terbukti). Hasil pengujian ini sesuai dengan hasil penelitian Leung \& Horwitz (2004) yang menyatakan bahwa direksi sudah mengetahui informasi lebih dahulu, namun terkadang tidak mengungkapkannya di laporan tahunan.

\section{PENUTUP}

Penelitian ini bertujuan untuk mengetahui pengaruh dari karakteristik dewan direksi dan struktur kepemilikan saham terhadap pengungkapan sukarela. Berdasarkan hasil pengujian, dapat diperoleh hasil sebagai berikut: (1) Variabel independen dan variabel kontrol secara simultan mempengaruhi pengungkapan sukarela; (2) Remunerasi dewan direksi dan kepemilikan institusional memiliki signifikansi hasil uji t di bawah 0,05 dengan nilai koefisien positif. Artinya dua variabel ini hipotesisnya terbukti mempunyai pengaruh signifikan positif terhadap pengungkapan sukarela; (3) Hasil pengujian parsial dari variabel independen lainnya yaitu ukuran, direksi independen, frekuensi rapat, direksi wanita, direksi bergelar ekonomi, direksi asing dan kepemilikan direksi tidak berpengaruh signifikan terhadap pengungkapan sukarela; (4) Variabel kontrol satupun tidak menunjukkan pengaruh signifikan terhadap pengungkapan sukarela.

Berdasarkan hasil dari data yang telah diolah yang menyatakan:

1.Variabel remunerasi dewan direksi berpengaruh signifikan positif terhadap tingkat pengungkapan sukarela. Hasil penelitian ini berarti bahwa remunerasi yang diberikan kepada dewan direksi pada perusahaan tergolong baik dan mampu mendorong mereka
Disclosure of Public

Institution

519 
Voluntary

Disclosure of Public

Institution

520 untuk mengungkapkan informasi secara sukarela.

2.Variabel kepemilikan asing berpengaruh signifikan negatif terhadap pengungkapan sukarela. Penelitian ini menunjukkan bahwa pengungkapan informasi kepada pemegang saham asing masih tergolong rendah karena adanya keterbatasan dalam beberapa faktor seperti komunikasi, bahasa dan geografis. Upaya tambahan perlu dilakukan untuk dapat meningkatkan pengungkapan kepada para pemangku kepentingan sehingga para pemangku kepentingan dapat mengambil keputusan dan tindakan dengan tepat.

3.Variabel kepemilikan institusional berpengaruh signifikan positif terhadap yang berarti kepemilikan oleh institusi memotivasi manajemen untuk memberikan pengungkapan sukarela yang lebih tinggi sehingga mengurangi asimetri informasi antara manajemen dan investor perihal kondisi keuangan maupun hasil operasi perusahaan.

Penelitian ini memiliki keterbatasan berupa indeks yang digunakan oleh peneliti merupakan indeks yang digunakan oleh peneliti lain dan pemberian nilai terhadap indeks yang mungkin berbeda dengan peneliti lain. Selain itu, masih banyak informasi yang tidak disajikan dalam laporan tahunan secara sukarela sehingga nilai yang diberikan peneliti kurang maksimal.

\section{DAFTAR PUSTAKA}

Agyemang, A. O., Yusheng, K., Ayamba, E. C., Twum, A. K., Chengpeng, Z., \& Shaibu, A. (2020). Impact of board characteristics on environmental disclosures for listed mining companies in China. Environmental Science and Pollution Research, 27(17), 2118821201. https://doi.org/10.1007/s11356-020-08599-2

Akhtaruddin, M., \& Abdur Rouf, M. (2012). Corporate governance, cultural factors and voluntary disclosure: Evidence from selected companies in Bangladesh. Corporate Board: Role, Duties and Composition, 8(1), 48-61. https://doi.org/10.22495/cbv8i1art4

Al-janadi, Y., \& Alazzani, A. (2016). Does government ownership affect corporate governance and corporate disclosure ?: Evidence from Saudi Arabia Article information : Managerial Auditing Journal Vol. 31 No. 8/9, 2016 Pp. 871-890, September. https://doi.org/10.1108/MAJ-12-2015-1287

Albawwat, A. H., \& Ali basah, M. Y. (2015). Corporate governance and voluntary disclosure of interim financial reporting in Jordan. Journal of Public Administration and Governance, 5(2), 100. https://doi.org/10.5296/jpag.v5i2.7580

Alfraih, M. M., \& Almutawa, A. M. (2017). Voluntary disclosure and corporate governance: empirical evidence from Kuwait. International Journal of Law and Management, 59(2), 217-236. https://doi.org/10.1108/IJLMA-10-2015-0052

Alhazaimeh, A., Palaniappan, R., \& Almsafir, M. (2014). The impact of corporate governance and ownership structure on voluntary disclosure in annual reports among listed jordanian companies. Procedia - Social and Behavioral Sciences, 129, 341-348. https://doi.org/10.1016/j.sbspro.2014.03.686

Alim, M., \& Ida. (2018). Faktor - faktor yang mempengaruhi pengungkapan laporan keuangan. Jurnal Manajemen Bisnis Program Pascasarjana Universitas Muhammadiyah Tangerang ISSN: 2302-3449 I e-ISSN: 2580-9490 Vol. 7I No. 2, Hal 81-88, 8(1), 16-23.

Alnabsha, A., Abdou, H. A., Ntim, C. G., \& Elamer, A. A. (2018). Corporate boards, ownership structures and corporate disclosures: Evidence from a developing country. Journal of Applied Accounting Research, 19(1), 20-41. https://doi.org/10.1108/JAAR01-2016-0001

Astuti, E. P. (2017). Pengaruh diversitas dewan direksi terhadap nilai perusahaan pada perusahaan manufaktur yang terdaftar di Bursa Efek Indonesia Periode 2008-2011. KREATIF : Jurnal Ilmiah Prodi Manajemen Universitas Pamulang, 4(2), 159-179.

Barros, C. P. (2013). Corporate governance and voluntary disclosure in France. The Journal of Applied Business Research, 29(2). https://doi.org/10.1057/jdg.2010.3

Bueno, G., Marcon, R., Pruner-da-Silva, A. L., \& Ribeirete, F. (2018). The role of the board in voluntary disclosure. Corporate Governance (Bingley), 18(5), 886-910. https://doi.org/10.1108/CG-09-2017-0205

El-diftar, D., Jones, E., Ragheb, M., \& Soliman, M. (2017). Institutional investors and 
voluntary disclosure and transparency : the case of Egypt. VOL. 17 NO. 1 2017, Pp. 134151, (C) Emerald Publishing Limited, ISSN 1472-0701 DOI 10.1108/CG-05-2016-0112. https://doi.org/10.1108/CG-05-2016-0112

Elfeky, M. I. (2017). The extent of voluntary disclosure and its determinants in emerging markets: Evidence from Egypt. Journal of Finance and Data Science, 3(1-4), 45-59. https://doi.org/10.1016/j.jfds.2017.09.005

Faisol. (2019). Peran pengungkapan sukarela dalam menentukan pengaruh kinerja keuangan terhadap nilai perusahaan. Jurnal Akuntansi Dan Ekonomi, 4(1), 1. https://doi.org/10.29407/jae.v4i1.12545

Firdaus, R. G. (2020). Pengaruh risiko, return, dan perekonomian Indonesia terhadap keputusan berinvestasi saat Covid-19. Jurnal Pasar Modal Dan Bisnis, 2(2), 115-128. https://doi.org/10.37194/jpmb.v2i2.43

García-meca, E., \& Sánchez-ballesta, J. P. (2010). The association of board independence and ownership concentration with voluntary disclosure: A meta-analysis. European Accounting Review Vol. 19, No. 3, 603-627, 2010, June 2013, 37-41.

Hidayat, M. (2017). Faktor-faktor yang mempengaruhi pengungkapan sukarela pada laporan tahunan sektor perbankan di Bursa Efek Indonesia. Jurnal Dimensi, Vol. 6, No. 1: 151172 Januari 2017 Issn: 2085-9996, 6(1), 151-172. https://doi.org/10.33373/dms.v6i1.531

Kartikarini, N., \& Mutmainah, S. (2013). Analisis pengaruh diversitas gender terhadap voluntary corporate governance disclosure dalam laporan tahunan perusahaan. Diponegoro Journal of Accounting, O(0), 200-214.

Kristie, O., \& Robin. (2016). Pengaruh tata kelola perusahaan terhadap nilai perusahaan pada perusahaan sektor keuangan yang terdaftar di BEI. Bina Ekonomi, 20(1), 1-22. https://doi.org/10.26593/be.v20i1.1893.1-22

Leung, S., \& Horwitz, B. (2004). Director ownership and voluntary segment disclosure: Hong Kong evidence. Journal of International Financial Management and Accounting, 15(3), 235-260. https://doi.org/10.1111/j.1467-646X.2004.00109.x

Mahayana, I. D. M., \& Bagiada, I. M. (2015). Pengaruh reputasi auditor dan tipe kepemilikan perusahaan pada pengungkapan sukarela laporan tahunan perusahaan manufaktur di Bursa Efek Indonesia. Jurnal Bisnis Dan Kewirausahaan. Vol 11. No. 1 Maret 2015, 11(1), 34-45.

Maskati, M. M. Al, \& Hamdan, A. M. M. (2017). Corporate governance and voluntary disclosure: Evidence from Bahrain. International Journal of Economics and Accounting, 8(1), 1. https://doi.org/10.1504/ijea.2017.084876

Melyana, R., \& Syafruddin, M. (2015). Pengaruh pengungkapan sukarela terhadap nilai perusahaan. Diponegoro Journal Of Accounting Volume 4, Nomor 2, Tahun 2015, Halaman 1-11 Issn (Online): 2337-3806, 4(2012), 1-11.

Mohd Ghazali, N. A., \& Weetman, P. (2006). Perpetuating traditional influences: Voluntary disclosure in Malaysia following the economic crisis. Journal of International Accounting, Auditing and Taxation, 15(2), 226-248. https://doi.org/10.1016/j.intaccaudtax.2006.08.001

Nainggolan, A. (2017). Pengaruh struktur kepemilikan dan komposisi dewan komisaris terhadap tingkat pengungkapan sukarela pada perusahaan manufaktur di Indonesia yang terdaftar fi BEI. Jurnal Akuntansi Dan Keuangan Methodist Eissn : 2599-1175 Volume 1, Nomor 1, 2017, 1-9 Issn : 2599-0136, 1, 1-9.

Neliana, T. (2018). Pengungkapan sukarela laporan tahunan dan faktor-faktor yang mempengaruhi. Jurnal Akuntansi Dan Keuangan FEB Universitas Budi Luhur Vol. 7 No. 1 April 2018 ISSN: $22527141,10(2), 1-15$.

Nofianti, N., Fatah, A., \& Tirtasari, N. (2018). Pengaruh pengungkapan sukarela terhadap kinerja keuangan dengan cost of capital sebagai variabel intervening. Journal of Applied Accounting and Taxation, 3(2), 168-173. https://doi.org/10.30871/jaat.v3i2.890

Ntim, C. G., Opong, K. K., Danbolt, J., \& Thomas, D. A. (2012). Voluntary corporate governance disclosures by post-apartheid South African corporations. Journal of Applied Accounting Research, 13(2), 122-144. https://doi.org/10.1108/09675421211254830

\section{Voluntary \\ Disclosure of Public \\ Institution}


Voluntary

Disclosure of Public Institution

522
Rasmini, N. K., Wirakusuma, G., \& Yuniasih, N. W. (2014). The effect of board diversity on the extent of intellectual capital disclosure (empirical study in Indonesian stock exchange). Asia Pacific Journal of Accounting and Finance, 3(31), 45-58.

Rodríguez Domínguez, L., \& Noguera Gámez, L. C. (2014). Corporate reporting on risks: Evidence from Spanish companies. Revista de Contabilidad-Spanish Accounting Review, 17(2), 116-129. https://doi.org/10.1016/j.rcsar.2013.10.002

Roudaki, J. (2018). Corporate governance structures and firm performance in large agriculture companies in New Zealand. Corporate Governance (Bingley), 18(5), 987-1006. https://doi.org/10.1108/CG-07-2018-0241

Samaha, K., Khlif, H., \& Hussainey, K. (2014). The impact of board and audit committee characteristics on voluntary disclosure: A meta-analysis. "Journal of International Accounting, Auditing and Taxation." https://doi.org/10.1016/j.intaccaudtax.2014.11.001

Saputra, E. (2014). Faktor-faktor yang mempengaruhi luas pengungkapan sukarela dan implikasinya terhadap asimetri informasi (Studi pada perusahaan manufaktur yang terdaftar di Bursa Efek Indonesia periode 2012-2014). Edi Saputra.

Sartawi, I. I. S. M., Hindawi, R. M., Bsoul, R., \& Ali, A. J. (2014). Board composition, firm characteristics, and voluntary disclosure: The case of Jordanian firms listed on the Amman Stock Exchange. International Business Research, 7(6). https://doi.org/10.5539/ibr.v7n6p67

Sefty, D., \& Farihah, I. (2016). Pengaruh ukuran perusahaan dan kepemilikan manajerial terhadap pengungkapan laporan keuangan. Jurnal Akuntansi. Vol. 3 No. 2. Juli 2016 ISSN 2339-2436, 3(2), 1-12.

Soejono, F. (2010). Ownership type and company performance: Empirical studies in the Indonesian stock exchange. Jurnal Ekonomi \& Bisnis Indonesia (Fakultas Ekonomi Dan Bisnis Universitas Gadjah Mada), 25(3), 338-352. https://doi.org/10.22146/jieb.6288

Subair, F. (2013). Karakteristik perusahaan dan industri terhadap pengungkapan dalam laporan keuangan pada perusahaan manufaktur yang go publik. Jurnal EMBA, 1(3), 763774.

Taran, A., Zahid, A., \& Mironiuc, M. (2017). Foreign ownership and financial disclosure in Central and Eastern Europe. Timisoara Journal of Economics and Business | ISSN: 22860991 | Www.Tjeb.Ro Year 2017 | Volume 10 | Issue 2 | Pages: 151-168 DOI: 10.1515/Tjeb-2017-0010, 10(2), 151-168. https://doi.org/10.1515/tjeb-2017-0010

Uyar, A., Kilic, M., \& Bayyurt, N. (2013). Association between firm characteristics and corporate voluntary disclosure : Evidence from Turkish listed companies. IC, $2013-$ 9(4): 1080-1112 - Online ISSN: 1697-9818 - Print ISSN: 2014-3214, 9(4), 1080-1112.

Vedanti Pratiwi, I. I., Badera, I. D. N., \& Budiartha, I. K. (2018). Kemampuan kepemilikan institusional memoderasi pengaruh diversitas gender, kebangsaan, pengalaman dewan pada luas intellectual capital disclosure. E-Jurnal Ekonomi Dan Bisnis Universitas Udayana, 2, 543. https://doi.org/10.24843/eeb.2018.v07.i02.p09

Wijayani, D. R., Budiman, N. A., \& Mulyani, S. (2019). Pengaruh corporate governence terhadap voluntary disclosure (study kasus pada perusahaan manufaktur di Bursa Efek $\begin{array}{lllll}\text { Indonesia pada tahun 2015-2017). Solusi, } & \text { 17(4). }\end{array}$ https://doi.org/10.26623/slsi.v17i4.1772

Wulandari, Y., \& Laksito, H. (2015). Analisis faktor-faktor yang mempengaruhi luas pengungkapan informasi sukarela pada laporan keuangan tahunan (Studi empiris pada perusahaan manufaktur yang terdaftar di Bursa Efek Indonesia tahun 2011-2013). Diponegoro Journal of Accounting, 4(3), 619-627.

Yunita, N. (2012). Pengaruh corporate governance terhadap voluntary disclosure dan biaya hutang. Jurnal Ilmiah Mahasiswa Akuntansi - Vol 1, No. 1, Januari 2012, 1(1), 90-96.

Zaheer, N. (2013). Effects of duality, board size and board composition on corporate governance disclosure in Pakistan. International SAMANM Journal of Finance and Accounting ISSN 2308-2356 October 2013, Vol. 1, No. 3, 1(3), 1-16. 